\title{
THE JUSTIFICATION OF CLINICAL PHARMACY SKILLS AND KNOWLEDGE FOR MODERN COMMUNITY PHARMACIST
}

\author{
Maja Koraćević1,2, Aleksandra Catić-Djordjević1 , Nikola Stefanović1 ${ }^{1}$ Ivana Damnjanović1 \\ Ivana Stošić ${ }^{1}$, Radmila Veličković-Radovanović1,3
}

\begin{abstract}
The course of pharmacy education has undergone a radical change as it aims to become more patient oriented. The primary objective of this study was to assess the association between clinical pharmacy education and daily activities of the community pharmacist (CP) including recognition and solution of drug-related problems (DRP). Furthermore, we wanted to investigate $\mathrm{CPs}^{\prime}$ attitudes regarding knowledge and skills that can be required for routine community pharmacy practice. The simple questionnaire was formed to evaluate the significance of the implementation of clinical pharmacy course in the education of CPs. The questionnaires were sent by post or email or they were provided directly by one of the researcher. Data acquired from 234 CPs were divided into two groups: clinical pharmacy education group (CPEG) and non-clinical pharmacy education group (NCEG). The most frequent DRP recognized by respondents (CPEG and NCEG) were drug interactions, followed by suboptimal efficacy of the treatment and inappropriate dosage selection. Additionally, CPEG statistically more frequently than NCEG recognized low adherence $(p<0.05)$, while NCEG more frequently recognized inappropriate dosing interval $(p<0.05)$ and omitted drugs, that should have been prescribed $(p<0.05)$. The respondents agreed that knowledge of drug therapy, therapeutic planning skills and critical evaluation of drug information skills were the most important clinical pharmacy skills and knowledge required for modern community pharmacy practice. Still, CPEG gave advantage to the knowledge of laboratory and diagnostic skills compared to NCEG $(p<0.05)$. This study indicated that clinical pharmacy education can move the focus of the CPs towards a patient, but still positions drug in the center of their activity. The pharmacists with the clinical pharmacy education considered the knowledge of laboratory and diagnostic skills to be of significant importance, which confirms the ongoing change in pharmacist orientation.
\end{abstract}

Acta Medica Medianae 2020;59(1):14-22.

Key words: clinical pharmacy, pharmacy practice, community pharmacy, pharmacy education

${ }^{1}$ University of Niš, Faculty of Medicine, Department of Pharmacy, Niš, Serbia

${ }^{2}$ University of Niš, Innovation Center, Niš, Serbia

${ }^{3}$ Clinic of Nephrology, Clinical Center Niš, Niš, Serbia

Contact: Aleksandra Catić-Đorđević

81 Dr. Zoran Djindjić Blvd., 18000 Niš, Serbia

E-mail: aleksandra1610@yahoo.com

\section{Introduction}

A community pharmacist (CP) has numerous responsibilities regarding patients and their medications in everyday pharmacy practice. A medication review is assumed to be the first activity, which is done by the pharmacists during their routine work in the pharmacy $(1,2)$. This activity implies recognition of potential or existing drug-related problems (DRP), such as no indication for a drug, the choice of drug, formulation of a drug, dosage regimen, drug interactions, adverse effects and drug's contraindication. Pharmacists' roles are evolving and therefore they are meant to deal not only with DRPs, connected to drug per se, but also with patients' adherence, quality of life, pharmacoeconomy issues and giving an appropriate and acceptable solution and a piece of advice as well $(2,3)$. Furthermore, the increasing number of new medications and dietary supplements requires critical evaluation, processing and sharing the information regarding that novelty from the pharmacists towards other healthcare professionals and patients $(3,4)$. To sum up, this all represents a real challenge for the modern pharmacist, which requires multidisciplinary skills and knowledge in order to handle it. Skills and knowledge that can be acquired in undergraduate or postgraduate course of clinical pharmacy, seem to be important and helpful for accurate, effective and prompt response to 
defined problems $(5,6)$. The course of pharmacy education has undergone a radical change as it aims at become a more patient oriented profession (7). Therefore, required knowledge and skills of a modern $\mathrm{CP}$ are communication skills, knowledge of drug therapy, nondrug therapy and complementary medicine, knowledge of the disease, laboratory and diagnostic skills, physical assessment skills, therapeutic planning skills and critical evaluation of drug information skills $(8,9)$. The successful communication seems to be the crucial regarding patient counseling, a leading tool in everyday pharmacy practice (10, 11). Additionally, academic pharmacy program can develop stronger collaborative relationships with practice sites, resulting in access to diverse patient care environments (12). Lots of information available nowadays enables patients to be more involved in their treatments, which gives an emphasis on the self-care/self-medication and consequently $\mathrm{CP}$ involvement. Self-medication risks may be severe unless they are controlled by a healthcare professional, who can notice potential harmful effects in appropriate time frame $(13,14)$. Also, there is always an urge of the patients to solve their problem as soon as possible in an acceptable manner, which makes community pharmacy first place to step in. The healthcare system needs an emphatic $\mathrm{CP}$, who possesses an active knowledge and could provide pharmaceutical care for achieving this goal (15-17).

The aim of this study was to assess the association between clinical pharmacy education and daily activities of the $\mathrm{CP}$ including recognition and solution of drug-related problems. Furthermore, we wanted to investigate $\mathrm{CPs}^{\prime}$ attitudes regarding knowledge and skills that can be required for routine community pharmacy practice.

\section{Novelty of the Work}

- This article indicated that clinical pharmacy skills and knowledge should have more important role in the curriculum of undergraduate studies of pharmacy and continuous education for community pharmacist as well.

- The course of clinical pharmacy may shape patient-focused pharmacist, who should be able more effectively to recognize and solve drug-related problems in everyday community pharmacy practice.

- The skills acquired through clinical pharmacy course will improve inter-professional co-operation, but will not transform pharmacist into physician.

\section{Respondents and methods}

The investigation was performed among CPs in the region of southeastern Serbia. The simple questionnaire was formed to investigate the significance of the implementation of clinical pharmacy course in education of the CPs. The questionnaire contained questions regarding demographic characteristics (gender, age) of the CPs and their education (clinical pharmacy course or not), the frequency of DRP recognized by $\mathrm{CP}$ and pharmaceutical inter- ventions provided to handle DRP and pharmacists' attitudes about required knowledge and skills for community pharmacy practice. The research was conducted between January and March 2015. Data were acquired from 234 Serbian CPs affiliated to Pharmaceutical Chamber of Serbia. The sample represents $22.7 \%$ of all CP in the region of southeastern Serbia (1030 members, data were reviewed on 24.03.2016). The pharmacists were supposed to voluntarily fill and return the questionnaire in two weeks. The questionnaires were sent to $282 \mathrm{CPs}$ by post or email or they were provided directly by one of the researcher as well. Of all sent questionnaires, 238 were returned, but only 234 were valid for statistical analysis and included into study. Respondents were divided into two groups based on their education of clinical pharmacy: clinical pharmacy education group (CPEG), who had undergraduate or postgraduate education in clinical pharmacy and nonclinical pharmacy education group (NCEG), who did not have any previous education in clinical pharmacy. The chi-square test was used to compare data between CPEG and NCEG. All analyses were performed with SPSS statistical analysis software, version 16.0 (SPSS, Chicago, IL, United States). The significance level was set at $p<0.05$.

Ethics approval: This type of study does not have ethics approval due to it was conducted on voluntary basis.

\section{Results}

Demographic data regarding respondents and number questionnaires are given in Table 1.

The results showed that high percentage of CPs $(84.4 \%)$ were willing to participate in this research. Female pharmacists were significantly more involved in the survey, with $90.6 \%$, while the CPEG contributes with $45.3 \%$ in the research.

The results of this study demonstrated that almost $40 \%$ of the CPs reported DRP and provided interventions more than three times a week, while $53 \%$ of the respondents recognized DRP once a week (Graph 1).

Graph 2 shows that the most frequent DRP were drug interactions, followed by suboptimal efficacy of the treatment and inappropriate dosage selection. Additionally, inappropriate drug selection and inappropriate dosing interval selection had high percent share in pharmacists' answers. Conversely, low adherence was present with a very small percentage.

Deffined groups of pharmacist (CPEG and NCEG) showed significant difference in frequency of the recognized DRPs (Graph 3). Both groups pointed out drug interactions ( $17 \%$ vs. $14 \%$ ) suboptimal efficacy of the treatment (14\% vs. $12 \%)$ and inappropriate dosage selection ( $12 \%$ vs. $13 \%)$ as the most significant, but CPEG statistically more frequently than NCEG recognized low adherence $(6 \%$ vs. $3 \%, p<0.05)$, while NCEG more frequently recognized inappropriate dosing interval ( $8 \%$ vs. $12 \%$, $\mathrm{p}<0.05$ ) and omitted drugs, that should have been prescribed $(2 \%$ vs. $5 \%, \mathrm{p}<0.05)$. 
Table 1. Statistical data regarding respondents and questionnaires

\begin{tabular}{|c|c|c|}
\hline & Number & Percentage \\
\hline Questionnaires (Returned/Sent) & $238 / 282$ & $84.4 / 100$ \\
\hline Questionnaires (Valid/Total) & $234 / 238$ & $98.3 / 100$ \\
\hline Respondents (CPEG / NCEG) & $106 / 128$ & $45.3 / 54.7$ \\
\hline Gender (M/F) & $22 / 212$ & $9.4 / 90.6$ \\
\hline Age & Years (median [range]) & \\
\hline CPEG & $27(25-45)$ & \\
\hline NCEG & $36(29-60)$ & \\
\hline
\end{tabular}

CPEG -group of community pharmacists with undergraduate or postgraduate education in clinical pharmacy; NCEG - group of community pharmacists with no prior education in clinical pharmacy

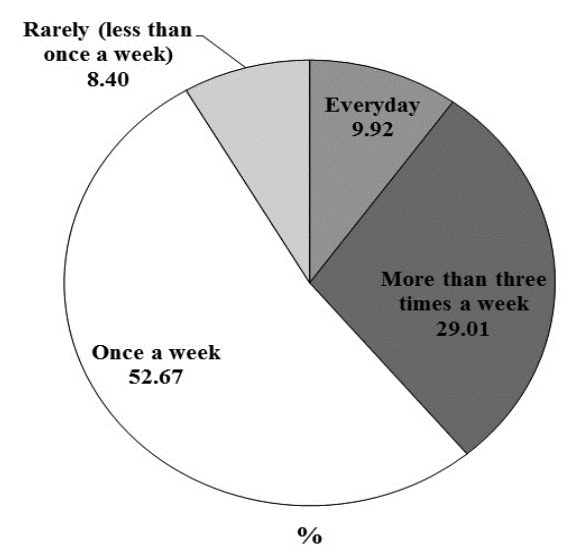

Graph 1. Frequency of recognized DRP and pharmaceutical interventions

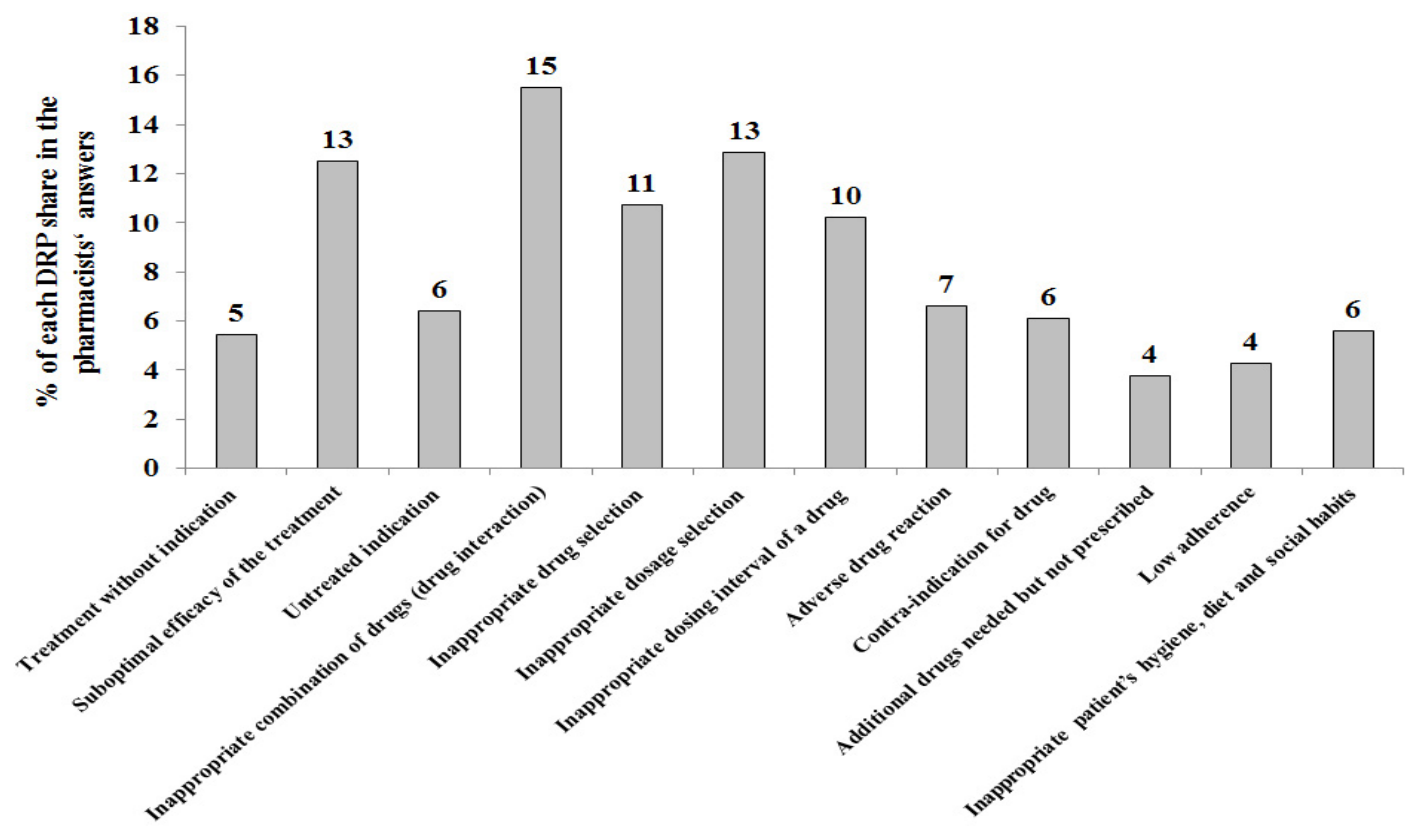

Graph 2. The DRP recognized by CP (CPEG+NCEG) 


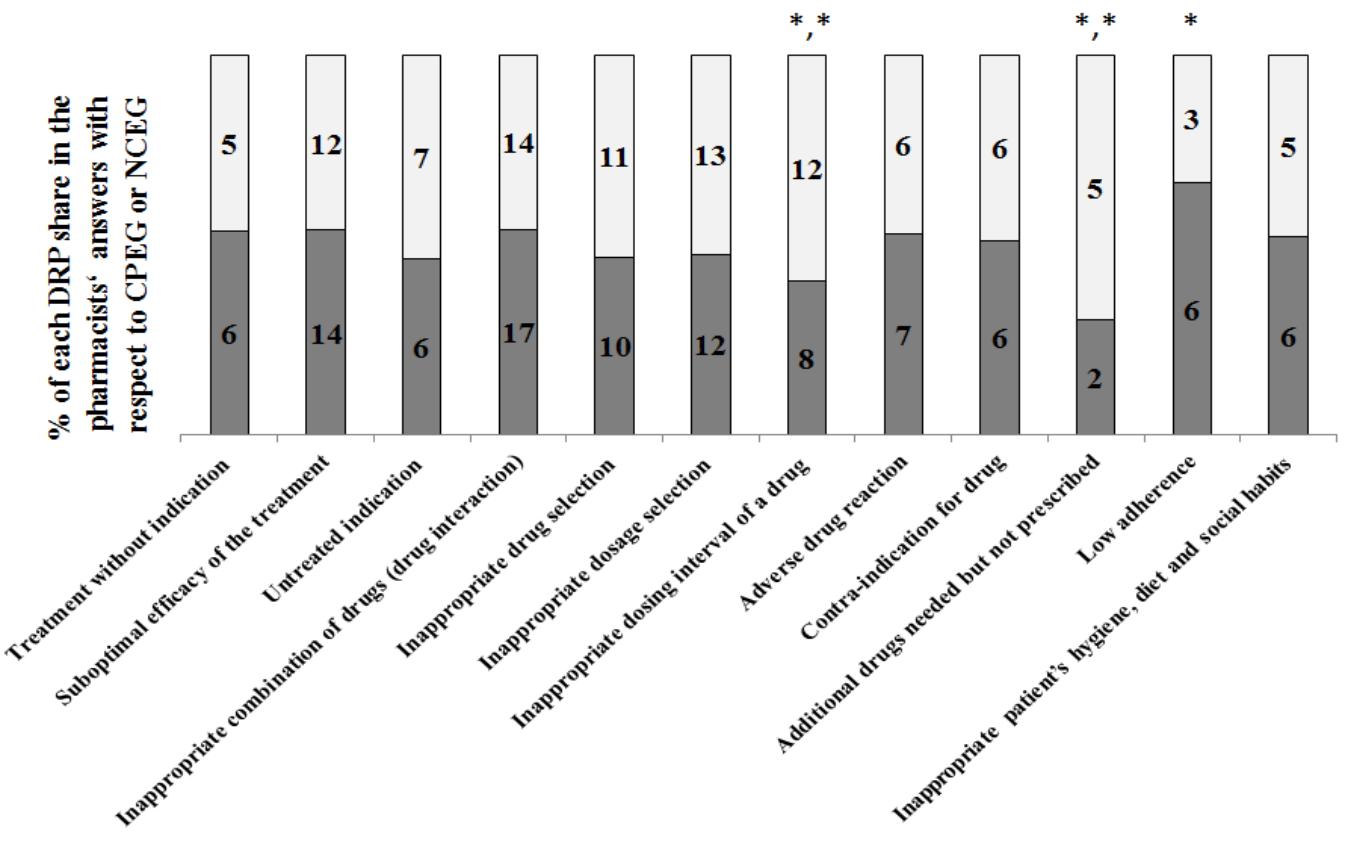

\section{$\square$ CPEG $\square$ NCEG}

*: CPEG vs. NCEG, p < 0.05; * *: NCEG vs. CPEG, $p<0.05$

Graph 3. The DRP recognized by CP in relation to previous clinical pharmacy education (CPEG vs. NCEG)

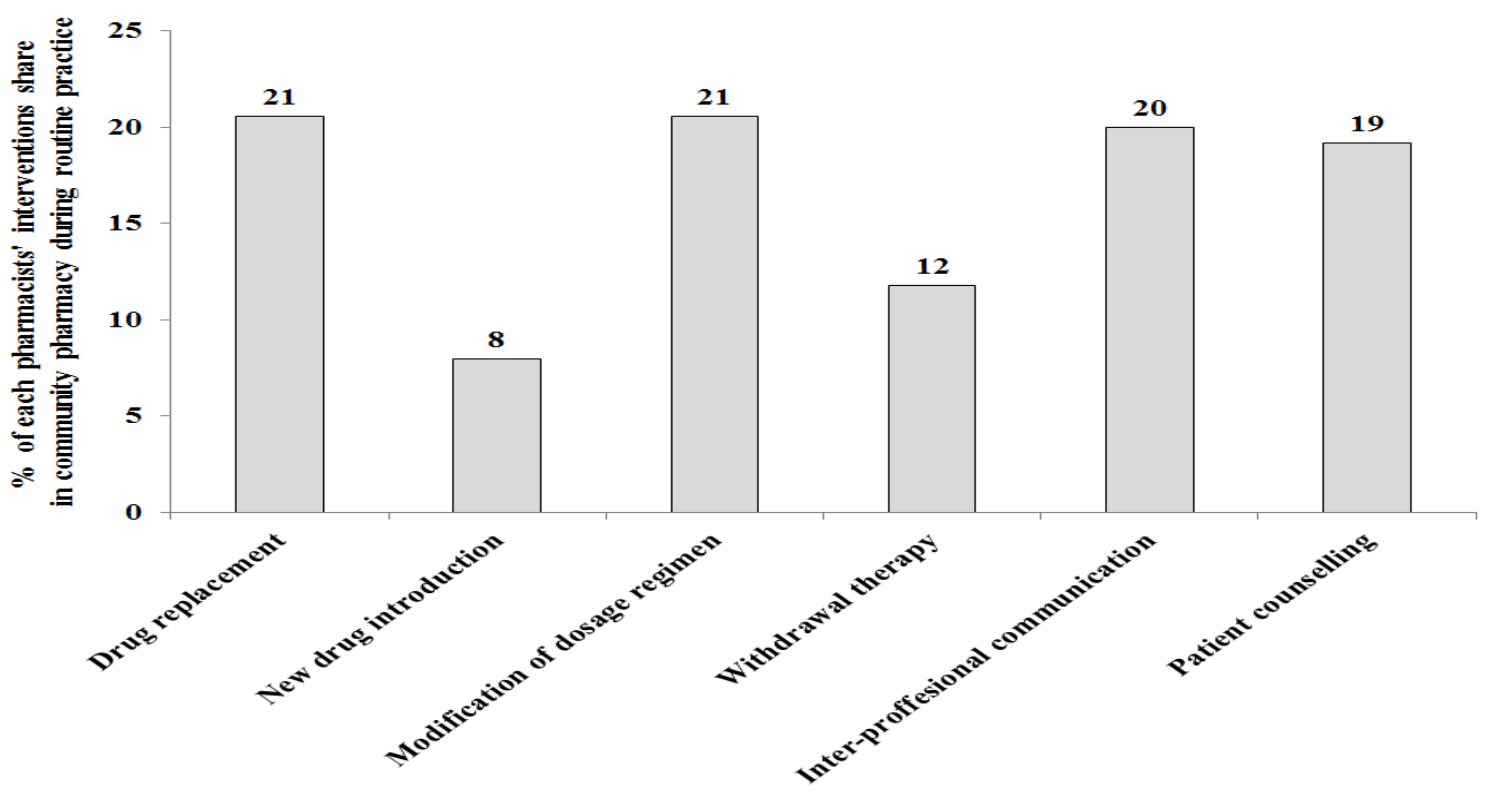

Graph 4. The frequency of pharmaceutical interventions provided by CPS

Graph 4 describes the pharmaceutical interventions provided by CPs. Drug replacement, modification of dosage regimen, interprofessional com- munication and patient counselling were almost equally provided. 
In order to recognize and solve DRPs pharmacists need certain skills and knowledge. Graph 5 shows CPs attitudes regarding required skills and knowledge for routine pharmaceutical practice.

The results of this study showed that knowledge of drug therapy (30\%), therapeutic planning skills (19\%) and critical evaluation of drug information skills $(13 \%)$ were the most important with respect to CPs for everyday practice.

Still, CPEG gave advantage to the knowledge of laboratory and diagnostic skills compared to NCEG $(p<0.05)$ (Graph 6).

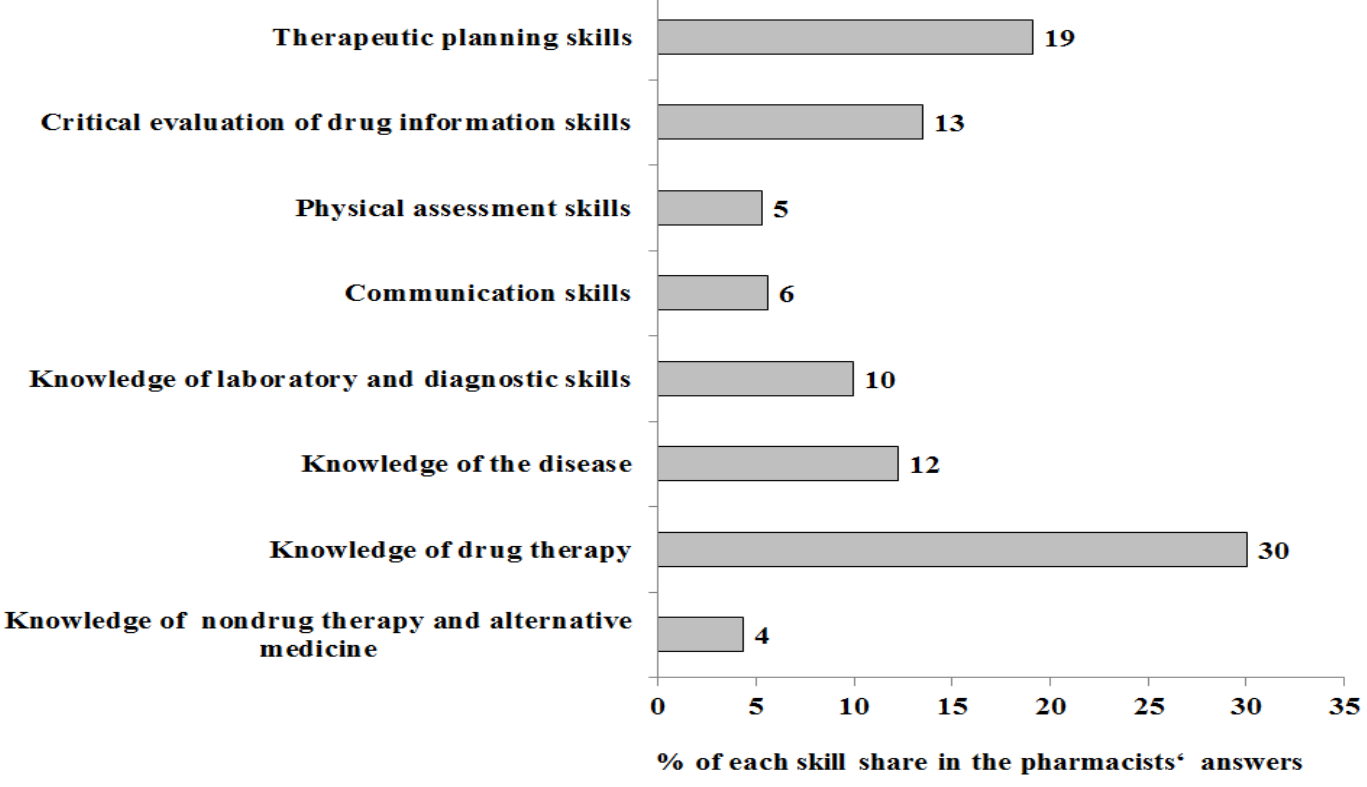

Graph 5. Pharmacists' attitudes regarding required skills and knowledge (CPEG + NCEG)

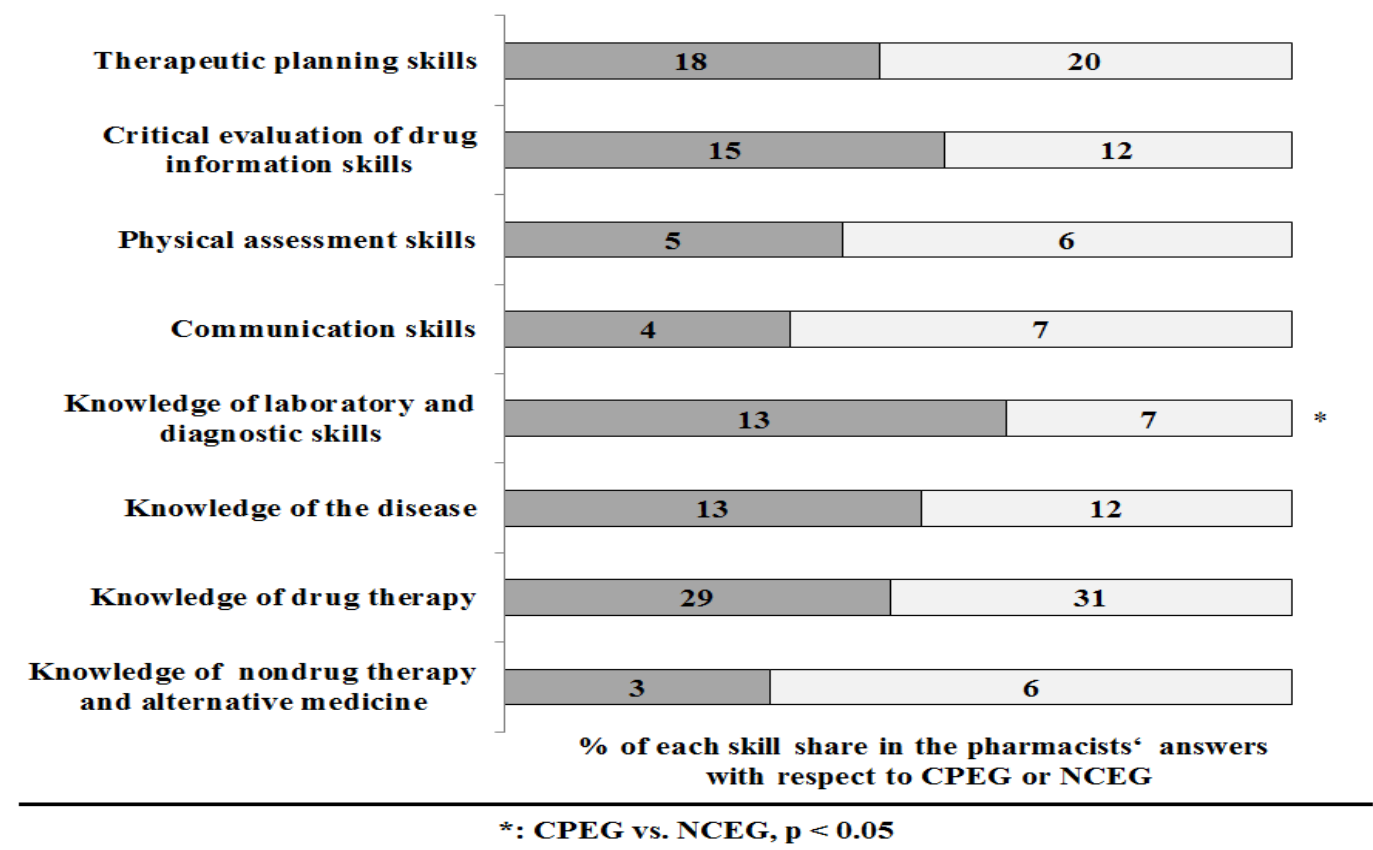

Graph 6. Pharmacists' attitudes regarding required skill and knowledge with respect to CPEG and NCEG 


\section{Discussion}

The modern pharmacists realize that community pharmacy is a place which offers exchange of the information and experience, and therefore contributes to the better relationship and communication between patient and his pharmacist, which lead to patients' adherence improvement (2, 12, 16). The ongoing globalization impacts the pharmaceutical practice creating pharmacy competence framework (18). "How should pharmacists be educated to increase the quality of their practice - by improving their knowledge of drugs' pharmacology, or by improving their managing and communication skills?", is important question nowadays (11). Community pharmacy in Serbia is the place for drug dispensing, prescribing over the counter drugs, and counselling about rational pharmacotherapy and chronic noncommunicable disease as well. There was ultimate need to increase the number of pharmacists in the world $(19,20)$. In Serbia, CPs with a clinical knowledge and skills is even more needed healthcare profession, considering the fact that undergraduate courses of clinical pharmacy have existed less than a decade. According to the studies of Lakic at al., Serbia had less pharmacists per 100,000 inhabitants than Bulgaria, Croatia and Slovenia, countries from the same European region (19).

Besides the need for more pharmacists, the $\mathrm{CPs}$ require continuous improvement of knowledge and skill important for patient-focused approach in pharmaceutical practice. Recent researches confirmed the need for constant promotion of pharmaceutical knowledge and skills for problem solving interventions in everyday practice $(21,22)$. Accordingly, the results of this study showed insufficient frequency of the recognition of DRP and consequently pharmaceutical interventions among study enrolled CPs (Graph 1). These findings can be partly explained by the fact that clinical pharmacy course has existed less than a decade in undergraduate pharmacy studies in Serbia. Also, this indicates that ongoing reforms of pharmacy educational system should be more pronounced regarding knowledge and skills and most importantly these reforms should be more patient-oriented (23). The introduction of electronic evidence of pharmaceutical interventions will be a new tool for gathering information regarding pharmaceutical service in Serbia and may contribute to overall improvement of community pharmacy service.

The results of the conducted study showed that the most frequent DRPs among respondents were drug interactions, followed by suboptimal efficacy of the treatment and inappropriate dosage selection. The research, conducted in Ireland, showed that medication review and check of the physician's decision can also be useful screening tools that determined prescribing errors and it may reduce unnecessary medication in prescriptions, and adverse event (24). In accordance to these findings, an association was found between increasing number of drugs and supplements and the appearance of the drug interactions and adverse effects among the older population (25).
The obtained results indicated that whether pharmacist had clinical pharmacy education or not, DRPs, such as drug interactions, treatment efficiency and inappropriate dosage selection were noticed most frequently. Nevertheless, clinical pharmacy may transform $\mathrm{CP}$ to the more patient-focused health professional, who perceives a patient in its entirety. In our investigation CPEG recognized low adherence statistically more frequent than NCEG, while NCEG recognized more often inappropriate dosing interval and omitted medication as well. This (leads to the conclusion) explains that CPEG is more oriented towards patients' problems and their behaviour during prescribed treatment. Conversely, NCEG is more focused on medication review and medication itself, with less interpersonal communication.

According to Westerlund et al., CPs noticed that patients' incomprehension of the aim of the therapy might cause low adherence and suboptimal treatment efficacy (26). Considering this, community pharmacy should be the place, which can provide additional explanation about patients health problems and treatment-disease association in order to achieve better compliance with the patients and therefore desirable therapeutical outcomes $(27,28)$.

The most frequent pharmaceutical interventions were done on medication, including its replacement and modification of dosage regimen. This finding is in accordance with the results of other authors, who investigated the knowledge and skills of clinical pharmacy required in everyday practice. Tasaka et al., noticed that implementation of clinical pharmacy skills in pharmaceutical practice led to positive therapeutic and financial outcomes, which had benefit both for community and the patient (6). Additionally, interprofessional communication and patient counselling were also highly rated in routine practice of CP.

The results of this study reported that both groups had the same attitudes regarding required knowledge and skills, emphasizing that knowledge of drug therapy (30\%) and therapeutic planning skills $(19 \%)$ were the most important. This medication-focused approach was followed by critical evaluation of drug information skills (13\%). Elliott et al. demonstrated that managing the therapeutic plan is one of the methods for better adherence (29). Still, pharmacists with previously acquired clinical pharmacy education gave a slight advantage to the knowledge of laboratory and diagnostic skills. It indicates that education of clinical pharmacy may cause the change from a medication- to a patientfocused pharmacist. Previous researches showed that CPs had less knowledge about signs and symptoms of the diseases, which was needed for appropriate pharmaceutical intervention and care of the patients as well $(21,30)$. This supports our finding that clinical pharmacy education may contribute to rational and timely decision regarding pharmacy-led interventions. The ultimate benefit of the introduction of these skills and knowledge can be demonstrated through improved patients' quality of life and reduced healthcare costs $(18,31)$. In accordance with this, the efforts on the national level have been made to improve Serbian pharmaceutical practice. 
The most important improvement will be electronic documentation of pharmaceutical intervention towards patients.

Considering these results, it was shown that clinical pharmacy education and courses had a significant influence on forming of a modern CP with a patient in its focus. Still, pharmacist, both CPEG and NCEG highlighted the importance of drug therapy skills, which indicated that they would not cross their initial obligations and try to be physicians. This can represent a real background for interprofessional cooperation between pharmacist and the other healthcare professionals. The newly obtained knowledge and skills may help pharmacist to deal with his or her tasks in responsible manner and therefore to optimize pharmacotherapy and cooperate with physician in order to provide a maximum safety and benefit for the patient.

\section{Conclusion}

In conclusion, CPs deal with different DRPs and provide pharmaceutical interventions within their daily activity. The results of this study indicated that education of clinical pharmacy skills and knowledge can move the focus of the CPs, from medicine towards patient, but still position the drug in the center of their activity. Modern pharmacist with changed skills in his or her portfolio gives a huge contribution to interprofessional approach with a view to achieve desired health outcomes. Pharmacist with clinical pharmacy education were more familiar with the knowledge of laboratory and diagnostic skills, necessary for the risk therapy management, which confirms the ongoing change in pharmacist orientation. Therefore, it is desirable that clinical pharmacy course should be part of the undergraduate curriculum of pharmacy students or continuous medical education for experienced pharmacist as well.

\section{Acknowledgement}

This work was supported by a grant awarded by the Faculty of Medicine, University of Niš (Grant INT-MFN 37 , Grant INT-MFN 25).
1. Anderson C, Bates I, Beck D, Brock TP, Futter B, Mercer $\mathrm{H}$ et al. The WHO UNESCO FIP Pharmacy Education Taskforce. Hum Resour Health 2009;7:45. [CrossRef] [PubMed]

2. Correr CJ, Melchiors AC, de Souza TT, Rotta I, Salgado TM, Fernandez-Llimos F. A tool to characterize the components of pharmacist interventions in clinical pharmacy services: the DEPICT project. Ann Pharmacother 2013;47:946-52. [CrossRef] [PubMed]

3. Basak SC, van Mil JW, Sathyanarayana D. The changing roles of pharmacists in community pharmacies: perception of reality in India. Pharm World Sci 2009;31:612-18. [CrossRef] [PubMed]

4. Salgado TM, Correr $\mathrm{CJ}$, Moles R, Benrimoj SI, Fernandez-Llimos F. Assessing the implementability of clinical pharmacist interventions in patients with chronic kidney disease: an analysis of systematic reviews. Ann Pharmacother 2013;47:1498-506. [CrossRef] [PubMed]

5. Alaqeel S, Abanmy NO. Counselling practices in community pharmacies in Riyadh, Saudi Arabia: a cross-sectional study. BMC Health Serv Res 2015; 15:557. [CrossRef] [PubMed]

6. Tasaka Y, Yasunaga D, Tanaka M, Tanaka A, Asakawa T, Horio I et al. Economic and safety benefits of pharmaceutical interventions by community and hospital pharmacists in Japan. Int J Clin Pharm 2016; 38:321-9. [CrossRef] [PubMed]

7. Shirwaikar A. Objective structured clinical examination (OSCE) in pharmacy education - a trend. Pharm Pract 2015;13:627. [CrossRef] [PubMed]

8. Barnett CW, Matthews HW. Teaching evaluation practices in colleges and schools of pharmacy. Am J Pharm Educ 2009;73:103. [CrossRef] [PubMed]

9. Tai BB, Hata M, Wu S, Frausto S, Law AV. Prediction of pharmacist intention to provide medication disposal education using the theory of planned behaviour. J Eval Clin Pract, 2016; [CrossRef] [PubMed]

10. Wallman A, Vaudan C, Sporrong SK. Communications training in pharmacy education, 1995-2010. Am J Pharm Educ 2013;77:36. [CrossRef] [PubMed] 
11. Puspitasari HP, Aslani P, Krass I. Pharmacists' and consumers' viewpoints on counselling on prescription medicines in Australian community pharmacies. Int J Pharm Pract, 2010;18:202-8. [CrossRef] [PubMed]

12. Rathbun RC, Hester EK, Arnold LM, Chung AM, Dunn SP. Importance of direct patient care in advanced pharmacy practice experiences. Pharmacotherapy 2012;32:e88-97. [CrossRef] [PubMed]

13. Veiga P, Lapão LV, Cavaco AM, Guerreiro MP. Quality supply of nonprescription medicines in Portuguese community pharmacy: An exploratory case study. Res Social Adm Pharm 2015;11:880-890. [CrossRef] [PubMed]

14. Damnjanovic I, Kitic D, Stefanovic N, ZlatkovicGuberinic S, Catic-Djordjevic A, Velickovic-Radovanovic R. Herbal self-medication use in patients with diabetes mellitus type 2. Turk J Med Sci 2015; 45: 964-71. [CrossRef] [PubMed]

15. Katoue MG, Awad AI, Schwinghammer TL, Kombian SB. Pharmaceutical care education in Kuwait: pharmacy students' perspectives. Pharm Pract 2014;12:411. [CrossRef] [PubMed]

16. Barnett MJ, Frank J, Wehring H, Newland B, Von Muenster $\mathrm{S}$, Kumbera $\mathrm{P}$ et al. Analysis of pharmacistprovided medication therapy management (MTM) services in community pharmacies over 7 years. J Manag Care Pharm 2009;15:18-31. [CrossRef] [PubMed]

17. Pande S, Hiller JE, Nkansah N, Bero L. The effect of pharmacist-provided non-dispensing services on patient outcomes, health service utilisation and costs in low- and middle-income countries. Cochrane Database Syst Rev 2013;2:CD010398 [CrossRef] [PubMed]

18. Anderson C, Bates I, Brock T, Brown AN, Bruno A, Futter B et al. Needs-based education in the context of globalization. Am J Pharm Educ 2012;76:56. [CrossRef] [PubMed]

19. Lakić D, Tasić L, Kos M, Petrova G, Stoimenova A, Krajnović D. Pharmacy network and access to medicines in selected eastern European countries: comparative analysis. Croat Med J 2012;53:53-9. [CrossRef] [PubMed]

20. Kheir N, Zaidan M, Younes H, El Hajj M, Wilbur K, Jewesson PJ. Pharmacy education and practice in 13 Middle Eastern countries. Am J Pharm Educ 2008; 72:133. [CrossRef] [PubMed]

21. Kashour TS, Joury A, Alotaibi AM, Althagafi M, Almufleh AS, Hersi A et al. Quality of assessment and counselling offered by community pharmacists and medication sale without prescription to patients presenting with acute cardiac symptoms: a simulated client study. Eur J Clin Pharmacol 2016;72:321-8. [CrossRef] [PubMed]

22. Lin K, Travlos DV, Wadelin JW, Vlasses PH. Simulation and introductory pharmacy practice experiences. Am J Pharm Educ 2011;75:209. [CrossRef] [PubMed]

23. Anderson C, Brock T, Bates I, Rouse M, Marriott J, Manasse $\mathrm{H}$ et al. Transforming health professional education. Am J Pharm Educ 2011;75:22. [CrossRef] [PubMed]

24. Galvin R, Moriarty F, Cousins G, Cahir C, Motterlini N, Bradley $M$ et al. Prevalence of potentially inappropriate prescribing and prescribing omissions in older Irish adults: findings from The Irish LongituDinal Study on Ageing study (TILDA). Eur J Clin Pharmacol 2014; 70:599-606. [CrossRef] [PubMed]

25. Peklar J, Henman MC, Kos M, Richardson K, Kenny RA. Concurrent use of drugs and supplements in a community-dwelling population aged 50 years or more: potential benefits and risks. Drugs Aging 2014; 31:527-40. [CrossRef] [PubMed]

26. Westerlund T, Gelin U, Pettersson E, Skärlund F, Wågström $K$, Ringbom $C$. A retrospective analysis of drug-related problems documented in a national database. Int J Clin Pharm 2013;35:202-9.

[CrossRef] [PubMed]

27. Morecroft CW, Mackridge AJ, Stokes EC, Gray NJ, Wilson SE, Ashcroft DM et al. Emergency supply of prescription-only medicines to patients by community pharmacists: a mixed methods evaluation incorporating patient, pharmacist and GP perspectives. BM] Open 2015;5:e006934. [CrossRef] [PubMed]

28. Horvat N, Kos M. Contribution of Slovenian community pharmacist counseling to patients' knowledge about their prescription medicines: a cross-sectional study. Croat Med J 2015;56:41-49. [CrossRef] [PubMed]

29. Elliott RA, Boyd MJ, Salema NE, Davies J, Barber N, Mehta RL et al. Supporting adherence for people starting a new medication for a long-term condition through community pharmacies: a pragmatic randomised controlled trial of the New Medicine Service. BM] Qual Saf 2015; [CrossRef] [PubMed]

30. Bajorek B, LeMay K, Gunn K, Armour C. The potential role for a pharmacist in a multidisciplinary general practitioner super clinic. Australas Med J 2015;8:5263. [CrossRef] [PubMed]

31. Waszyk-Nowaczyk M, Nowaczyk P, Simon M. Physicians' and patients' valuation of pharmaceutical care implementation in Poznan (Poland) community pharmacies. Saudi Pharm J 2014;22:537-44. [CrossRef] [PubMed] 


\title{
OPRAVDANOST STICANJA VEŠTINA I ZNANJA IZ KLINIČKE FARMACIJE TOKOM OBRAZOVANJA SAVREMENOG FARMACEUTA
}

\author{
Maja Koraćević1,2, Aleksandra Catić-Đorđević ${ }^{1}$, Nikola Stefanović ${ }^{1}$, Ivana Damnjanović ${ }^{1}$, \\ Ivana Stošić ${ }^{1}$, Radmila Veličković-Radovanović1,3
}

\begin{abstract}
${ }^{1}$ Univerzitet u Nišu, Medicinski fakultet, Odsek za farmaciju, Niš, Srbija;
Univerzitet u Nišu, Inovacioni centar, Niš, Srbija;

${ }^{3}$ Klinika za nefrologiju, Klinički centar Niš, Niš, Srbija;
\end{abstract}

Kontakt: Aleksandra Catić-Đorđević

Bulevar dr Zorana Đinđića 81, 18000 Niš, Srbija

E-mail: aleksandra1610@yahoo.com

Savremeni farmaceut $u$ apoteci suočava se sa brojnim zahtevima vezanim za pregled terapije i uočavanje problema vezanih za terapiju (drug-related problems - DRP) bolesnika. Pored poznavanja leka, farmaceut danas aktivno učestvuje u ukupnoj terapiji bolesnika, savetuje i pomaže rešavanju manjih zdravstvenih problema izborom leka u režimu izdavanja bez lekarskog recepta. Sledeći nove obaveze farmaceuta u apoteci, akademsko obrazovanje farmaceuta transformisano je u nameri da se fokus pomeri sa leka na bolesnika. Primarni cilj ovog istraživanja bila je procena povezanosti obrazovanja iz kliničke farmacije i dnevnih aktivnosti farmaceuta u apoteci (community pharmacist - CP), uključujući prepoznavanje i rešavanje DRP. Osim toga, cilj je bio i izvršiti analizu stavova CP-a u pogledu znanja i veština koje mogu biti korisne u svakodnevnom radu. Istraživanje je sprovedeno pomoću jednostavnog upitnika formulisanog za procenu značaja uvođenja veština kliničke farmacije u akademske studije. U istraživanju je čestvovalo $234 \mathrm{CP}-\mathrm{a}$, koji su podeljeni u dve grupe: grupa sa edukacijom iz kliničke farmacije (CPEG) i grupa bez edukacije iz kliničke farmacije (NCEG). Najčešći DRP, koji su prepoznali ispitanici (CPEG i NCEG), su interakcije lekova, praćene suboptimalnom efikasnošću lečenja i neodgovarajućim doziranjem. Dodatno, CPEG su značajno češće uočavali nisku adherencu $(p<0,05)$, a NCEG neprikladan interval doziranja $(p<0,05)$ i lekove koji nedostaju, a mogli bi biti korisni u terapiji $(p<0,05)$. Ispitanici su se složili da su poznavanje lekova, veštine planiranja i rukovođenja terapijom i kritička procena informacija o lekovima najvažnije veštine i znanja iz kliničke farmacije potrebne za svakodnevni rad u apoteci. Ipak, CPEG su dali prednost poznavanju laboratorijskih i dijagnostičkih veština $(p<0,05)$. Uočena razlika u važnosti poznavanja laboratorijskih i dijagnostičkih parametara potvrđuje pomeranje fokusa CPEG. Sprovedeno istraživanje pokazalo je da obrazovanje iz kliničke farmacije može pomeriti fokus CP-a ka bolesniku, ali i dalje sa lekom u centru farmaceutske aktivnosti.

Acta Medica Medianae 2020;59(1):14-22.

Ključne reči: klinička farmacija, farmaceutska praksa, obrazovanje farmaceuta 